UDC 658.5: 338.34

JEL: M00, M11, 015

\section{Larysa Borysova}

Candidate of Economic Science, Odessa I.I.Mechnikov National

University, Odessa, Ukraine

orcid.org/ 0000-0002-5760-4126

\section{Ludmila Borysova}

Candidate of Economic Science, Associate Professor, Odessa Institute of Trade and Economics of Kyiv National University of Trade and Economics, Odessa, Ukraine orcid.org/ 0000-0002-7285-6903

Received: January, 2018

Accepted: March, 2018

(C) Economics. Ecology. Socium, 2018 CC BY-NC 4.0 license

\section{INFLUENCE OF LIFE CYCLE STAGES OF THE SMALL AND MEDIUM ENTERPRISE ON CREATION OF THE EFFICIENT ORGANIZATIONAL STRUCTURE}

Introduction. In modern economics, small and medium enterprises are the majority of all functioning enterprises and a basis of each industry and sphere of economy. Therefore, they are relevant to the research of the activity of these enterprises by an organizational component as basic element of the general management. It is noted that development of these enterprises happens continuously, dynamically with the cyclic character, which demands continuous improvement of approaches to the organization of its activity and structure. Creation and development of it needs to be correlated depending on the current life cycle stage. The question about the expediency of change or improvement of the existing organizational structure at the small and medium enterprises depending on the stage of their lifecycle is raised.

Aim and tasks. The purpose of the article is to form the approach to interrelation of development of small and medium enterprises and their organizational configuration at different stages of their life cycle. According to the aim, the tasks are to analyze the current level of these enterprises' development and to investigate interrelation of the cyclical nature of their development with creation of effective organizational structure depending on a life cycle stage.

Research results. It is reasonable that a certain type of organizational configuration corresponds to each life cycle stage, and is optimal for it: it gives an opportunity to consider dynamics of its development, priorities and features, simplify the choice of organizational structure to the management of small and medium enterprises. This research showed the necessity to gradually integrate the process approach to the existing organizational structure on the 2nd lifecycle stage. Such approach creates anticrisis flexible organizational structure taking into account features of the whole enterprise's life cycle. Thus, project life cycle was defined. Its successful completion is necessary to correlate with the enterprise's life cycle. The carried-out analysis displayed the 4th stage as critical for development of the enterprises. To prevent this, it is necessary to use the development strategy on the 3rd stage already, implementing the innovation technologies, which define the new processes. The result is the renewal of organizational structure on the basis of process-functional approach.

Conclusions. The formation of the enterprise organizational structure depending on the current life cycle stage and its features, taking into account cycles of its development, simplify the choice of an organizational component for the management of the small and medium enterprises with use of the principles of the recognized in management and the most efficient process approach. It also provides certain flexibility of the organizational component of these enterprises in need of new product development, the organization of the project teamwork, determination of the beginning and termination of the project life cycle.

Key words: project life cycle, life cycle of enterprise, organizational structure, small and medium enterprises, process functional approach. 
УДК 658.5: 338.34

JEL: M00, M11, 015

\section{Лариса Борисова}

Кандидат економічних наук, викладач,

Одеський національний

університет імені I.I. Мечникова, Одеса, Україна

orcid.org/ 0000-0002-5760-4126

\section{Людмила Борисова}

Кандидат економічних наук, доцент,

Одеський торговельно-

економічний інститут

Київського національного

торговельно-економічного

університету,

Одеса, Україна

orcid.org/ 0000-0002-7285-6903

Отримано: Січень, 2018

Прийнято: Березень, 2018

(C) Економіка. Екологія. Соціум, 2018

CC BY-NC 4.0 ліцензія

\section{ВПЛИВ СТАДІЙ ЖИТТЕВОГО ЦИКЛУ МАЛИХ ТА СЕРЕДНІХ ПІДПРИЕМСТВ НА ПОБУДОВУ ДІЕВОЇ ОРГАНІЗАЦІЙНОЇ СТРУКТУРИ}

Проблема. У сучасних умовах господарювання базисом кожної 3 галузей та сфери економіки є малі та середні підприємства, які складають переважаючу долю усіх функціонуючих вітчизняних підприємств. Розвиток цього типу підприємств має певний циклічний характер, що вимагає постійного вдосконалення підходів до організації діяльності та оргструктури, побудову якої необхідно співвідносити в залежності від поточної стадії життєвого циклу. Так порушується питання доцільності зміни або вдосконалення наявної оргструктури малих та середніх підприємств в залежності від стадії життєвого циклу їх.

Мета та завдання. Метою статті є формування підходу щодо співвідношення розвитку малих та середніх підприємств та їх організаційної складової на різних стадіях життєвого циклу. Відповідно до мети повстало завдання проаналізувати сучасний стан розвитку цих підприємств та дослідити взаємозв'язок циклічності їх розвитку 3 побудовою дієвої оргструктури в залежності від стадії життєвого циклу.

Результати. Обгрунтовано, що кожній окремій стадії життєвого циклу відповідає певний тип оргструктури, який є оптимальним: надає змогу враховувати динаміку його розвитку, пріоритети та особливості, допомагає спростити вибір оргструктури керівництвом малих та середніх підприємств. Проведене дослідження показало, доцільність вже на II стадії життєвого циклу поступово інтегрувати до існуючої оргструктури впроваджуючи елементи процесного підходу. Такій підхід дає можливість сформувати антикризову гнучку оргструктуру з урахуванням усіх циклів, що формують життєвий цикл підприємства. Також було виділено життєвий цикл проекту, який для успішного завершення необхідно співвідносити з загальним життєвим циклом малих та середніх підприємства, а саме 3 ï III стадією життєвого циклу. Проведений аналіз виявив IV стадію як критичну для розвитку малих та середніх підприємств. Для запобігання цьому вже на III стадії зростання підприємствам необхідно вдаватися до стратегії розвитку, впроваджуючи інноваційні технології, продукти та послуги та визначити нові процеси, притаманні новітнім технологіям, i, відповідно, сформувати нову оргструктуру на основі процесно-функціонального підходу.

Висновки. Формування оргструктури, залежно від стадії життєвого циклу підприємства 3 урахуванням циклічності його розвитку й особливостей поточної стадії, дає змогу спростити вибір організаційної складової управління малими та середніми підприємствами 3 використанням засад визнаного найбільш дієвого підходу в управлінні - процесного. Це також надає певної гнучкості організаційної складової малих та середніх підприємств при необхідності розробки нового продукту, організації роботи проектної групи, виділення моменту початку життєвого циклу проекту та його припинення.

Ключові слова: життєвий цикл проекту, життєвий цикл підприємства, організаційна структура, малі та середні підприємства, процесно-функціональний підхід. 
Introduction. Stability of economy of Ukraine, improvement of the population's life of our country is subject to further development of small and medium business. This is particularly essential for the domestic economy as the share of small and medium enterprises makes more than $99 \%$ of actually working organizations as for the end of 2016 [1].

One small or medium enterprise employs 22 people on average. At the same time the negative tendency of reduction of employees' number in small and medium enterprises is noted as the expected response to reduction of demand, inflation, increase in the tax rates, the general unstable political and socially economic situation in Ukraine. Such approach to reduction of a position in the market is not always reasonable, and sometimes is even caused by lack of knowledge concerning opportunities of recovery from the crisis and further development.

In the present article, we offer one of the methods of crisis management, which is based on accounting of dynamics of the enterprise development, which is displayed in use of different approaches to management of small and medium enterprises and affects creation of their organizational structure. The last cannot be created once at the beginning stage of the enterprise's foundation and stay permanent for the entire period of its operation.

The organizational structure has to be flexible, develop according to the stages of the enterprise life cycle and take into account all cycles, which form it (life cycle of a product (service), life cycle of technology, life cycle of production, life cycle of the project etc.). Such structure also considers duties and responsibility of each worker and reduces probability of employment and work of "unnecessary" workers who cannot be in a lay off staff then.

Formation of organizational structure, depending on a stage of life cycle of the enterprise, taking into account cyclical nature of its development and features of the current stage, gives an enterprise the chance to simplify the choice of an organizational component of business management. Moreover, a precondition of successful performance of small and medium enterprises is use of results of modern researches in the management of organizations.
Process approach in management is recognized to be the most effective at creation of system of management of the enterprise, therefore formation of the organizational structure on its basis is expedient. Such approach also provides a certain flexibility of the organizational component of small and medium enterprises in need of development of a new product, the organization of work of a project group, determination of the moment of the beginning of the project life cycle and its termination. The latter comes at achievement of a certain result - a product or service, which is launched into the regular production. It already provides transition from a reduction stage to a new stage of growth. Therefore, the problem of research into relationship between the enterprise life cycle and creation of its organizational component and the project life cycle for maintenance of stable performance of small and medium domestic enterprises is relevant.

Analysis of recent researches and publications. Number of foreign and domestic scientists are engages in studying the practice and searching for the ways of stable performance of small and medium enterprises, among them are P.T. Kolisnichenko [1], K. Pavliuk [2], R. Gupta [4], O. M. Svintsytska [3], A. Lester[5], etc.

Other scientists, K.L. Carvalo [7], A. Dziubina [6] in particular, are studying the cyclic component of the enterprises development. Issues of human resource development have found reflection in the works of M. Santana, R. Valle [8] and others.

Main purpose of the article. The purpose of article is formation of approach to the relationship between small and medium enterprises development and their organizational component at different stages of the life cycle.

Previously unsettled problem constituent. Despite existence of a significant number of scientific publications on the discussed subject, problems of formation of the methodical principles concerning identification of the relationship between the enterprise life cycle and creation of its organizational component and also possibility of the enterprise growth and transformation at new level from the reduction stage. 
This is possible with the involvement of the project life cycle and contraction of organizational structure in compliance with the current life cycle stage of small and medium enterprises for ensuring further sustainable development due to the launch of a competitive product not only for domestic, but also for foreign ultimate consumers.

Results and discussions. According to the Public administration of statistics of Ukraine, small and medium enterprises form the basis for social and economic development of the country in general. It found reflection in "The strategy of sustainable development "Ukraine - 2020" where it is noted that such enterprises are basis of national economy due to the stable operation and creation of jobs they promote growth of gross national product, increase in competitiveness of production (services) and growth of innovative capacity of the organizations.

At the same time, these entities are vulnerable to the crisis phenomena in domestic economy. The lack of social and economic support programs and assistance to development of small and medium business also becomes a negative factor. These could be preferential financing, the tax concessions, investment and educational programs for small and medium business, educational programs for managers, etc.

Analyzing data noted in table 1 it is possible to state that the higher number of the population is employed at small and medium enterprises (more than $80 \%$ in total of working). At the same time, growth of the sold products volumes in terms of money can be explained, unfortunately, by growth of an exchange rate and inflation. It is also confirmed by negative financial results of activity of small and medium enterprises in recent years $[1, p$. 80].

While in absolute measures (tab. 1) the number of all enterprises has been gradually decreasing since 2014 and in 2016 in comparison with 2015 , the number of the big enterprises has decreased the most - by $23 \%$, the number of medium and small enterprises has decreased by $9 \%$ and $3 \%$ respectively. It already indicates certain constancy in a situation of reduction of the enterprises. In addition, the similar tendency will remain, so far, small and medium enterprises will not get the corresponding support from the state and also will not focus on new and more effective approaches to management of the enterprises, proceeding from modern economic researches.

External factors that influence operation of the enterprise are objective in the majority, therefore small and medium enterprises have to consider and adapt to them. At the same time, the internal organization of activity is subjective for small and medium enterprises, that is depends on an economic entity. Therefore it can be constructed by the management of the enterprise taking into account its potential and opportunities. Depending on a stage of development of the enterprise, its potential opportunities differ. It causes the necessity of studying cyclical nature of development of small and medium enterprises.

There are already enough researches on life cycles of goods, the enterprise, technology, but not enough attention is paid to consideration of development of the enterprise organizational structure from a position of the life cycle of the enterprise.

Most of the new enterprises are created without development of the organizational structure model. At the initial stage such approach is justified, both from the point of view of management, and from the point of view of economy of financial resources.

Development of the enterprise and increase in the number of staff (heads, workers, experts, employees and others) produces the need for ordering of their work, duties, subordination, hierarchy for further creation of motivational system. In addition, simple, most likely, functional organizational structure is not able to fulfil these requirements any more. It becomes clear that the structure of the enterprise depending on its requirements has to be adapted according to the modern approaches to management at the enterprises. 
Economics. Ecology. Socium, 2(1), 2018

Table 1. The key structural indicators of the enterprises in relation to their sizes

\begin{tabular}{|c|c|c|c|c|c|c|}
\hline \multirow{3}{*}{ Enterprise } & \multicolumn{6}{|c|}{ Years } \\
\hline & \multicolumn{2}{|c|}{2014} & \multicolumn{2}{|c|}{2015} & \multicolumn{2}{|c|}{2016} \\
\hline & Quantity & $\begin{array}{l}\text { In } \% \text { to } \\
\text { total }\end{array}$ & Quantity & $\begin{array}{c}\text { In } \% \text { to } \\
\text { total }\end{array}$ & Quantity & $\begin{array}{l}\text { In } \% \text { to } \\
\text { total }\end{array}$ \\
\hline \multicolumn{7}{|c|}{ Amount } \\
\hline Quantity, units (odes.) & 1932161 & 100 & 1974318 & 100 & 1865530 & 100 \\
\hline Big enterprises, odes. & 497 & 0,02 & 423 & 0,03 & 383 & 0,02 \\
\hline Medium enterprises, odes. & 16618 & 0,78 & 15510 & 0,92 & 15113 & 0,81 \\
\hline Small enterprises, odes. & 1915046 & 99,2 & 1958385 & 99,05 & 1850034 & 99,17 \\
\hline \multicolumn{7}{|c|}{ Quantity of employs } \\
\hline Quantity, thousand persons & 8796,7 & 100 & 8180 & 100 & 8108,3 & 100 \\
\hline $\begin{array}{c}\text { Big enterprises, thousand } \\
\text { persons }\end{array}$ & 1915,1 & 21,77 & 1708,6 & 20,89 & 1586,6 & 19,57 \\
\hline $\begin{array}{c}\text { Medium enterprises, } \\
\text { thousand persons }\end{array}$ & 2766,4 & 31,45 & 2632,7 & 68,58 & 2649,9 & 32,86 \\
\hline $\begin{array}{l}\text { Small enterprises, thousand } \\
\text { persons }\end{array}$ & 4115,2 & 46,78 & 3838,7 & 46,93 & 3871,8 & 47,75 \\
\hline \multicolumn{7}{|c|}{ The volume of the sold products (goods, services) } \\
\hline $\begin{array}{c}\text { Quantity, million grn. (MM } \\
\text { grn) }\end{array}$ & 4459702,2 & 100 & 5556540,4 & 100 & 6726739,8 & 100 \\
\hline Big enterprises, $M M$ grn. & 1742507,9 & 39,07 & 2053189,5 & 36,95 & 2391454,3 & 35,55 \\
\hline $\begin{array}{c}\text { Medium enterprises, } M M \\
\text { grn. }\end{array}$ & 1735894,2 & 38,92 & 2184376,8 & 39,31 & 2683303,5 & 39,89 \\
\hline Small enterprises, $M M$ grn. & 981300,1 & 22,00 & 1318974,1 & 23,74 & 1651982,0 & 24,56 \\
\hline
\end{tabular}

Source: Author's calculations on a basis [1, 11].

Therefore, depending on a stage of cyclic development, that is transformation of model of structure and actions of the management depends on a stage of life cycle of small and medium enterprises. In most cases, foreign and domestic heads employ the strategy of staff reduction, but it is not always the right decision, especially, if the enterprise "goes through difficult times". Domestic small and medium-sized enterprises are presented in the majority in the following spheres of action: wholesale and home shopping service, repair of vehicles and motorcycles; operations with real estate; transport, warehouse farms, post and express activity; activity in the sphere of administrative and support service, construction; agricultural industry, hunting and forestry (Fig. 1).

The population, private firms and public institutions use products and services of small and medium enterprises. These enterprises also try to export the production for which necessary criterion is its competitiveness. It has become especially relevant with receiving the status of the full participant of the Convention of Pan-Euro-Med by Ukraine after signing of the Law of Ukraine No. 2187 of November 8th,
2017 "About accession of Ukraine to the Regional convention about the Pan-EuroMediterranean preferential rules of origin". It is the tool developed by the EU for cooperation with the trade partners and the last among themselves and will promote creation of conditions for simplification of trade and increase in the Ukrainian export. The Ukrainian producers will also have to compete with highquality European import. The latter needs the development, the implementation and use of the latest approaches to the organization and management of small and medium enterprises, for example, such as approach to the organization of management based on the enterprise life cycle.

The data provided in [10, p.138-152] and the conducted researches demonstrate that the stage of founding (establishment) differs from the subsequent stages: the enterprise only begins the existence. The organizational component at this stage is in a formation phase therefore some values of data for calculating separate components of the generalizing indicator can be absent, because the organizational structure has the simplified appearance and is only being formed. 


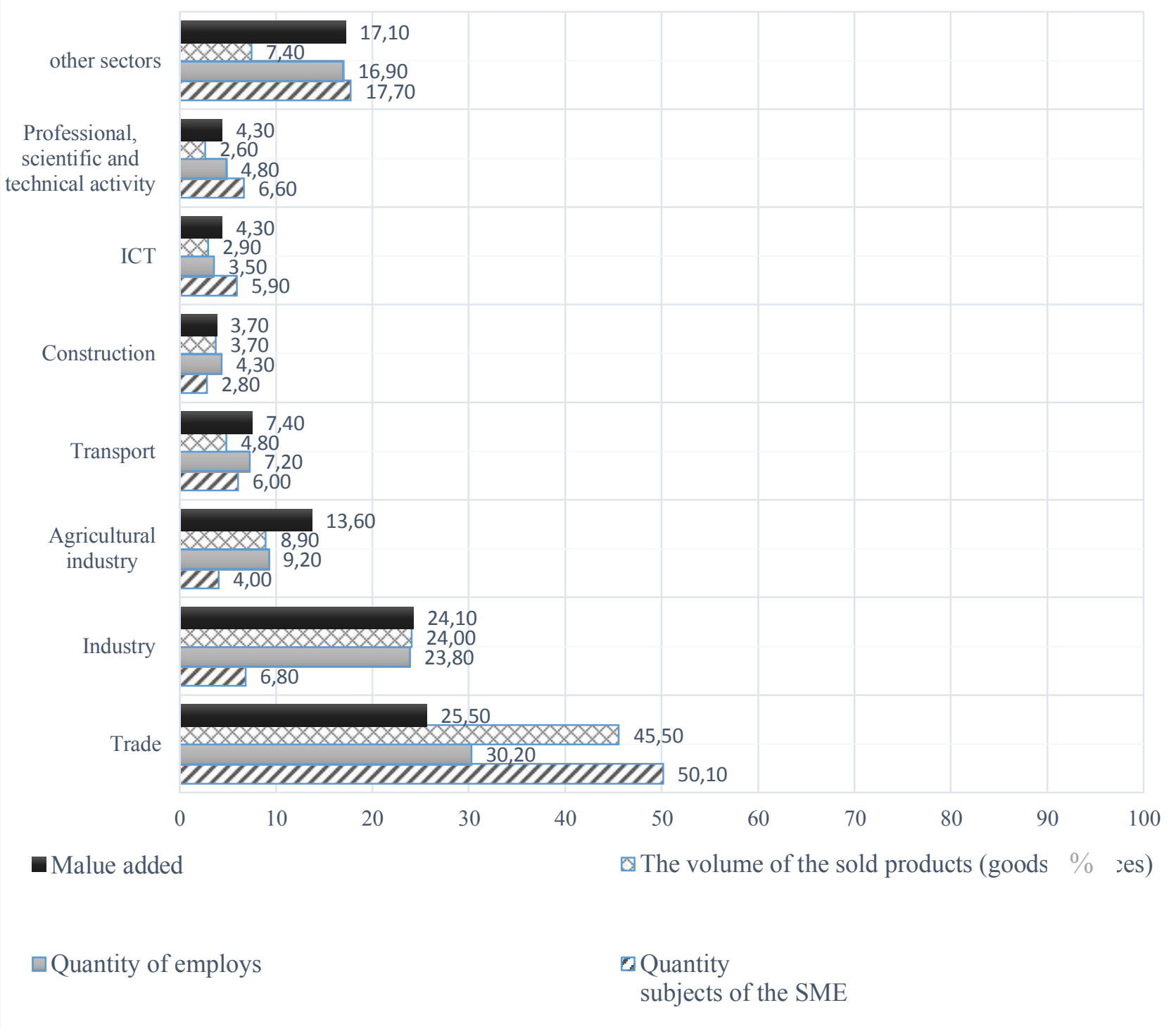

Fig. 1. Number of small and medium enterprises by industries in 2016 year.

Source: formed on a basis [11].

At the initial stage, there is no clear division of the staff into performers and managers, at this stage element of complex organizational structure only arise. Consequently, on the 1 st stage of the life cycle with growth of indicators of sale or rendering of services, a considerable amount of the staff (heads, workers, experts, employees, etc.) increases disproportionally to the needs, and, as a result, the quality of rendering of services worsens, demand for services of this small or medium enterprise, etc. falls. It has to become a signal to modification of the existing organizational structure and, perhaps, to increase in the staff.
On the 2nd stage of life cycle the enterprise extends, processes of production or/and rendering of services are defined. A process part of organizational model and a prerequisite of decentralization of functions of management (planning, account, control and the analysis) is formed, the system of motivation and regulation is organized. There are determination of the higher (where the business strategy of the enterprise is formed) and lower (on which operational and current activity on the basis of the defined processes is carried out) levels of organizational structure, which gives the enterprise opportunities to operate more effectively, using organizational structure that combines horizontal and vertical 
levels. More information on activity of the enterprise is available, which can become a data source for carrying out a research on efficiency of the current organizational structure at small and medium enterprises.

In view of the main reason of the enterprise foundation, its organizational structure has to be focused on requirements of an ultimate consumer. Already created structure has to independently solve and be able to overcome the problems connected with changes of the external environment. Thus, we come to conclusion that at this stage it is expedient to continue application of the line-functional organizational structure and include into it elements of process organizational model $[9, \mathrm{p}$. 61-63].

Another important factor on the way of development of the process-focused structure is its role as a basis of further improvement and changes in the existing organizational structure. Thus, the latter provides organizational component with more flexibility and a possibility of further development and integration into the general control system. Impossibility to further develop and integrate it at small and medium enterprises as one of control system components, will lead to new unplanned expenses, loss of professionals, which will exert negative impact on activity of such enterprises.

At this stage of life cycle the management staff has to be formed, or is already created under the influence of the objective economic laws connected with control, regulation, motivation, etc. However, at this stage the situation when workers can combine the manager's position with a position of "owner" of business process is still observed. Therefore, on the 2nd stage it is impossible to figure out stability of management staff as mostly it is still created from owners. An initial stage of formation of integral functional-process organizational structure also relates to the lack of definition of the centers of responsibility and accurate determination of management staff, the shortage of indicators, uncertain duration of an administrative cycle, etc. There is a need of urgent improvement of organizational structure of small and medium enterprises, namely: definition of processes and assignment of responsible staff etc. If this stage does not produce further development of small and medium enterprises, and displays "primary" development, which is the development of the most domestic small and medium enterprises, then it is identical to a goods cycle.

If we consider development of already working enterprise, then this stage has to coincide with development and result of the project, which will remove or already removed the enterprise on the 2nd stage again. Here it should be noted that the enterprise in the procedure of the creation and existence should not pass through only one life cycle, and in this case each enterprise would be created for further elimination (or bankruptcies) on the 4th stage. The latter contradicts the purpose of creation of the enterprise, from what we draw a conclusion that the enterprise needs to be updated (to employ new strategies of development for the existing products or services, to develop and introduce new products). This implies to move to a new level by the principle of evolutionary development. For this purpose, it is necessary to put an opportunity for changes of organizational structure in the development strategy, which leads to its flexibility and adaptability. The third stage of the life cycle is characterized by already created organizational structure of the enterprise with the allocated processes on the principles of process and functional approach (fig. 2). If the enterprise on the 3rd stage of the life cycle did not come to the similar type of organizational structure (which in the structure considers allocation of processes), then the situation is characterized by existence of a negative indicator of decentralization, duplication of functions (a negative side of functional creation of organizational structure), weak controllability. This also implies a negative indicator of rationality of structure creation and leads to increase in expenses on excessively increased list of heads, etc. The undeveloped organizational structure on the $3 \mathrm{rd}$ stage of the life cycle is also a negative tendency, which needs the careful analysis and further improvement in those places where shortcomings were revealed.

The organizational structure on the 3rd stage of the life cycle of small and medium 
enterprises is further development of the structure of 2nd stage of the life cycle [9, p.63]. The research based on the analysis of the scientific works $[9,13,14,16]$ has shown that this structure is subject to improvement in development of the enterprise and transition to other stages of life cycle. At the same time, improvement has to display emergence and definition of new economic processes in activity of the enterprise and, besides, to promote optimum definition of the center's responsibility for these processes (with a possibility of their allocation in separate department). During the development and emergence of new goods or services, creation of new department is not necessary, but assignment of exact experts in project group and appointment of responsible personnel is possible. It causes creation of a project group (fig. 2) and integration of it into the organizational structure at the second level (most likely, into department of marketing or production (constructor office). Also it gives the structure certain flexibility, helps to use financial resources rationally (as at its initial stage it is expedient to acquaint specialists of small and medium enterprises with the project).

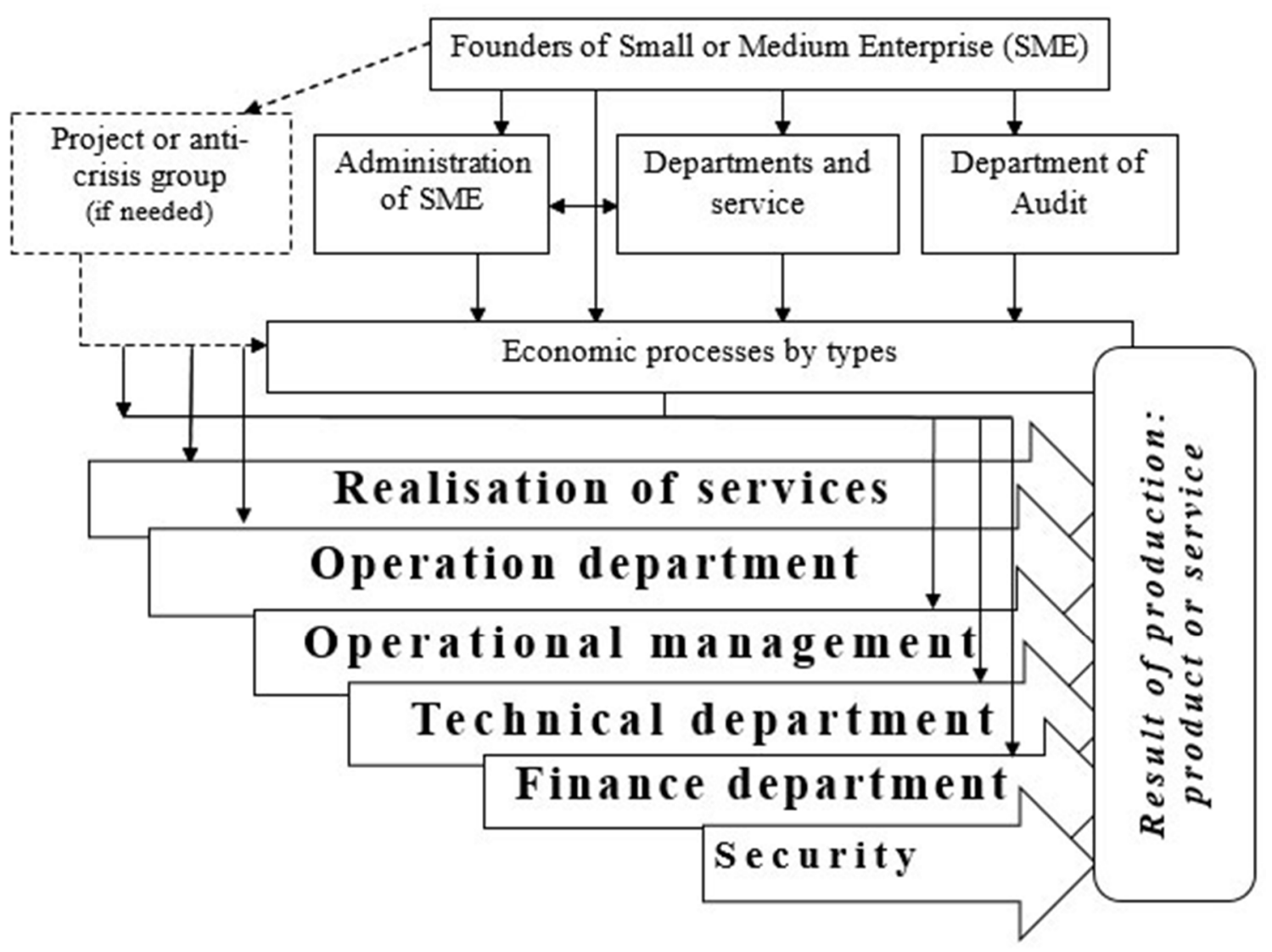

Fig. 2. Organizational structure of small and medium enterprises for the 3rd life cycle stage.

Source: developed by author

At the 4th stage of life cycle the organizational structure has a flexible and adaptive form, and its control system is effective. At the same time, it objectively needs more time for implementation of any decision, as the bigger number of staff is involved in this process. The last circumstance can negatively influence decision-making processes, its embodiment in production and process of rendering of services. However, this stage, proceeding from the review of the conducted researches, is critical, especially for small and medium-sized enterprises.

At the 4th stage of the life cycle the key question of further development of the enterprise appears. There are two options: reduction or revival of small and medium enterprises whose development comes to an 
end of the third stage of life cycle for the dynamic and innovative market to choose. Especially it concerns the enterprises of the knowledge-intensive spheres and branches (for example, spheres of telecommunication in which more than $35 \%$ of all working domestic enterprises operate). It causes creation of new services and products.

Innovations can have the supporting or breakthrough character. If the small or medium enterprise follows the supporting strategy of development of production or rendering of services, it misses the moment of change of strategy of rendering of services, when it reached the limit of its potential. In that case, the small or medium enterprise gradually loses positions on commodity market (services) and ceases to exist. Under such circumstances, the issue of development of organizational structure is replaced with an issue of rational contraction or elimination.
If the small and medium enterprise accepts the strategy of introduction of innovative products and services as optimal, it has certain opportunities for revival, that is to transition from the fourth to the second stage of the life cycle.

This process can be graphically presented in the form of the scheme (fig. 3), where it is visually visible that the previous $\mathrm{T} 1$ technology changes into the latest $\mathrm{T} 2$ technology at early stages of the life cycle, preventing transition of the enterprise to a reduction stage. For realization of the given processes, the enterprise has to define accurately new engineering and administrative procedures, which arise and form the relevant organizational structure of a certain type (fig. 2). It will promote increase in efficiency of the enterprise operation under new technological conditions.

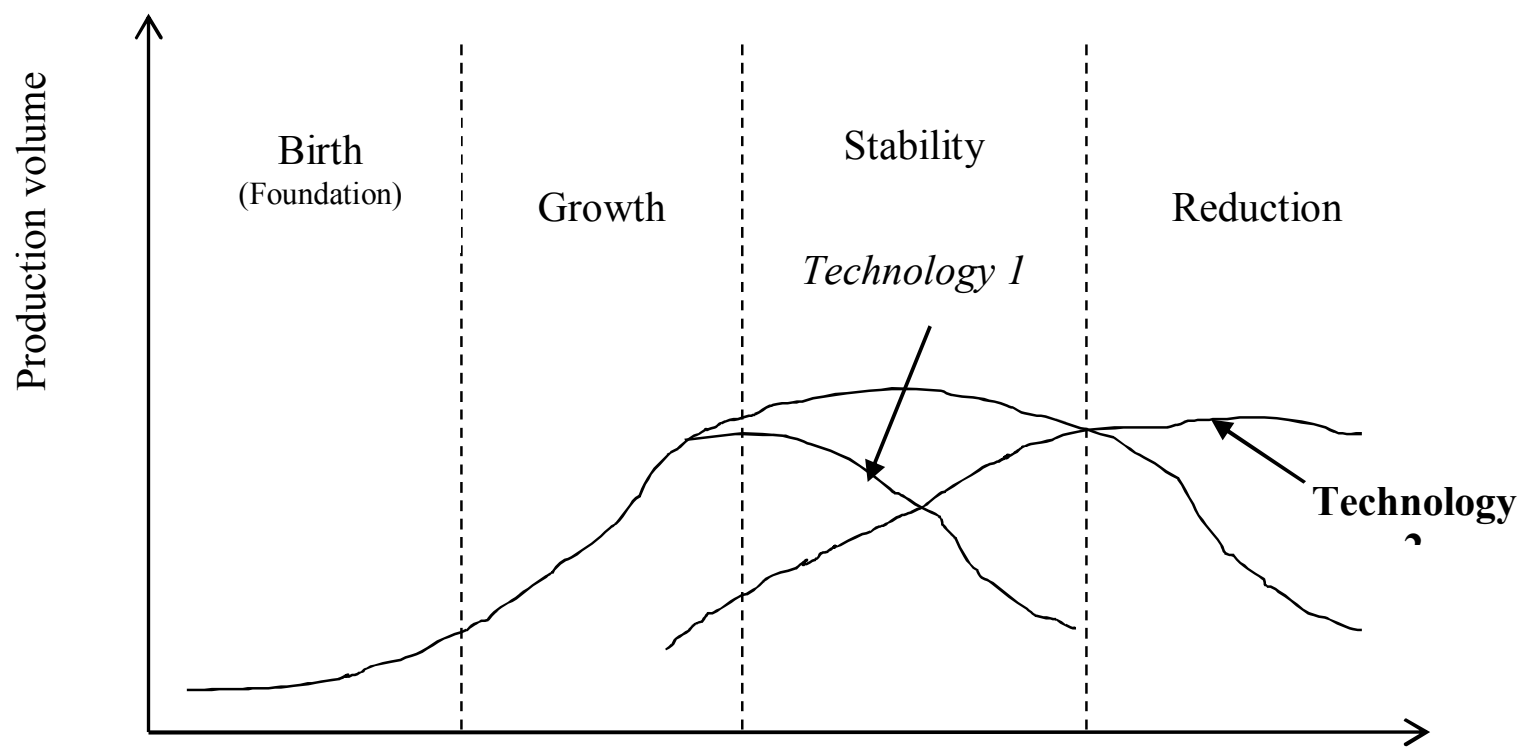

Fig. 3. Life cycle of small and medium enterprises with introduction of innovative technology.

Source: author's development on a basis [13, 14, 15]

Change of the latest technology demands a certain understanding of relationship between the technology life cycle and the development life cycle of the enterprise. At the same time for development, certain shots in project group (fig. 2) will be defined. It can also be a case when the project group becomes crisis management group by means of development of a new product (service) or the considerable improvement of already existing one. Thus, the project cycle (fig. 4) appears among the set of life cycles. 


\begin{tabular}{|c|c|c|c|c|c|c|}
\hline $\begin{array}{l}\text { Concept of a new } \\
\text { product (service) }\end{array}$ & $\begin{array}{l}\text { Possibility of } \\
\text { performance } \\
\text { and introduction } \\
\text { of the project }\end{array}$ & $\begin{array}{l}\text { The } \\
\text { coordinated } \\
\text { definition of } \\
\text { the project }\end{array}$ & $\begin{array}{l}\text { Development } \\
\text { and } \\
\text { subsequent } \\
\text { development. }\end{array}$ & $\begin{array}{c}\text { Final } \\
\text { product } \\
\text { (service) }\end{array}$ & Production & $\begin{array}{c}\text { Regular } \\
\text { (continuous) } \\
\text { production }\end{array}$ \\
\hline 1 & 2 & 3 & 4 & 5 & 6 & 7 \\
\hline \multicolumn{6}{|c|}{ Life cycle of a project } & \\
\hline
\end{tabular}

\section{Fig. 4. Relationship between the life cycle of small and medium-sized enterprises and its separate components.}

Source: author's development on a basis [13, p.50]

The latter begins from the moment of introduction of the latest $\mathrm{T} 2$ technology:

1. Life cycle of the project is the period of the concept search for a new product, its development which coincides with the mission of the company and its products (services), calculations of the lowest production options at prime cost, search for investors or sponsors (that is the cheapest financial resources for introduction of the project in real production). Design group carries out planning and control.

2. Life cycle of a product is the period of introduction of the project based on use of new $\mathrm{T} 2$ technology and obtaining result in the form of a certain new product (service). At this stage presence of investors or sponsors is considerable as this stage shows whether the result of the project is profitable, if business needs new financial resources for performance, or it is not of interest to the market at all. Responsibility, planning and control are gradually transferred from a design group directly to staff.

3. Life cycle of the enterprise is the period of full product launch into production, it stops being in a stage of "pilot" development, engages in its production permanent members of staff (heads, workers, experts, employees, etc.). The regular departments of small and medium enterprises exercise responsibility, planning and control.

Thus, new life cycle of the enterprise has to correspond to introduction of the new T2 technology. The backwardness of organizational structure of small and medium enterprises will lead to a number of shortcomings of the new project development, which will do much harm to usual operation of small and medium enterprises: strengthening of load of shots, increase in financial expenses, increase in time of passing through all necessary stages for end of the project, etc.

The listed shortcomings, especially at small and medium enterprises, most likely, will result in crisis state of economic entity, which can cause its elimination or bankruptcy as in domestic practice the credits for sanitation of such enterprises are mostly provided for the state or private big enterprises. Such position is aimed to increase probability of return of credit resources.

Internal shortcomings also become complicated with external factors of decline in business activity of small and medium enterprises [9, p. 24-28].

The following are some of the most essential obstacles (tab. 2).

The main obstacles in a way of development of domestic small and mediumsized enterprises are low demand for the manufactured products or services (there are not enough orders) that was noted by more than $64 \%$ of business entrepreneurs in comparison with $56 \%$ of legal entities; an unstable political situation - is noted by more than $47 \%$ of business entrepreneurs in comparison with $43 \%$ of legal entities; high rates of taxes were defined by more than $38 \%$ of legal entities in comparison with $29 \%$ of business entrepreneurs [10, p. 25]. Unfortunately, the situation with low demand in 2018 will worsen further in connection with growing quantity of the import market products, which are better in technology and are the best quality goods or services. In turn high rates of taxes will also not promote decrease in product cost that is a negative for increasing its competitive attractiveness for final consumers, etc. 
Table 2. Main obstacles for development of domestic small and medium enterprises in 2016-2017 years

\begin{tabular}{|c|c|c|c|}
\hline & \multirow[t]{2}{*}{ Obstacles } & \multicolumn{2}{|c|}{ Small and medium enterprises } \\
\hline & & Enterprise* & Business entrepreneurs $* *$ \\
\hline 1 & Not enough orders / low demand & $56 \%$ & $64 \%$ \\
\hline 2 & Unstable political situation & $43 \%$ & $47 \%$ \\
\hline 3 & High rates of taxes & $38 \%$ & $29 \%$ \\
\hline 4 & Burdensome tax administration, accounting & $29 \%$ & $22 \%$ \\
\hline 5 & Frequent changes of the economic legislation & $29 \%$ & $18 \%$ \\
\hline 6 & Inflation & $25 \%$ & $27 \%$ \\
\hline 7 & High regulatory pressure & $25 \%$ & $27 \%$ \\
\hline 8 & Corruption & $22 \%$ & $24 \%$ \\
\hline 9 & Not enough skilled workers & $22 \%$ & $17 \%$ \\
\hline 10 & War in the East of Ukraine & $21 \%$ & $18 \%$ \\
\hline 11 & High level of the competition & $20 \%$ & $18 \%$ \\
\hline 12 & Low availability of the credits & $19 \%$ & $19 \%$ \\
\hline
\end{tabular}

Source: author's development on a basis [10, p.25]

For this reason, small and medium businesses have to focus, first and foremost, on "strengthening" of internal structure and opportunities for resistance to external obstacles. It is necessary to develop the enterprises from a position of new approaches, considering the cyclic nature of development and according to this nature to carry out changes in management and reorganization of already functioning enterprise.

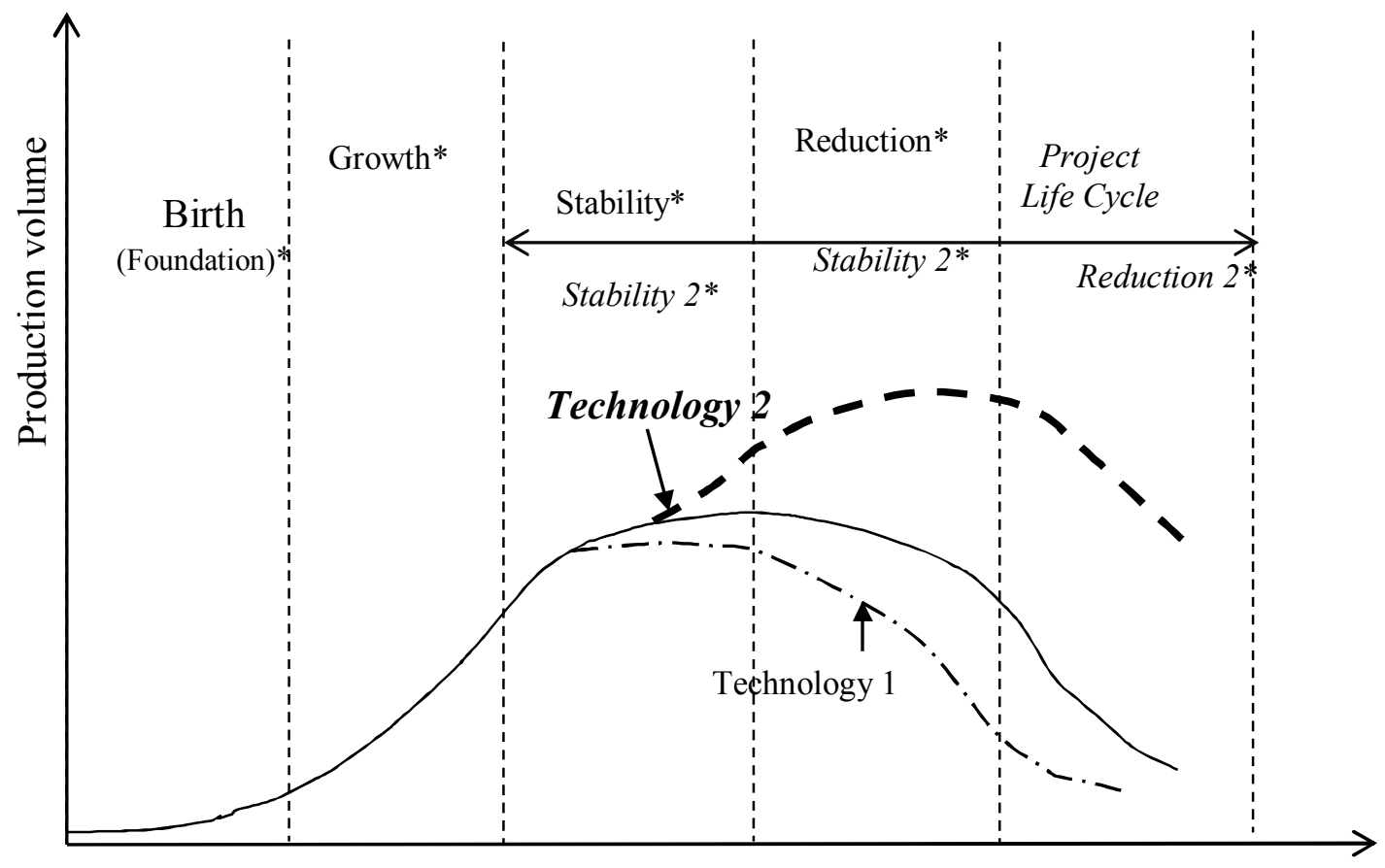

Time of existence of enterprise

* the beginning (first) life cycle of small and medium enterprises,

$2 *$ - life cycle of implementation of the new growth technology T2 (marked with the stroke line), marked with point and stroke, if technology T1 is provided

Fig. 5. Life cycle of implementation of growth technology $\mathrm{T} 2$ and the project life cycle.

Source: own author's development 
The similar schematic development model of different cycles of the enterprise with the choice of different development strategies indicates that the positive scenario of development needs creation of a certain organizational structure at the enterprise as it was revealed (fig. 5) earlier, taking into account features of operation in a certain sphere or the industry. The similar model of an organizational structure will provide necessary flexibility and adaptability not only to certain internal barriers, but also to firmness against a large number of external obstacles (tab. 2.).

Conclusions and further researches directions. The small and medium enterprises are fundamentals of domestic economy. Their stable development is the key to permanent social and economic growth of the country. At the same time, these enterprises are the most vulnerable to internal and external obstacles to stable operation. Accumulation of these obstacles results in crisis state of the small and medium enterprises and their further possible liquidation (bankruptcy). For prevention of these actions small and medium enterprises, as well as the big enterprises, have to use modern approaches to the management and organization of their activity. One of such approaches is the process approach to management, which also has to be displayed in organizational structure of small and medium enterprises.

The study and the analysis of its results have demonstrated that transition to new organizational structure in terms of small and medium enterprises has to be done only on the 2nd stage of the enterprise life cycle. Therefore, we need to study activity of the enterprise based on the cyclic nature of development. This approach gives an enterprise the opportunity to reduce the burden of human and financial resources, to develop the enterprise and to reconstruct its organizational structure. It also helps the management and the administration of the small and medium enterprise to reveal the exact moment (or opportunities) of introduction of growth technology without excess expenses. Thus above-mentioned showed coincidence of this implementation and a final interval of a growth phase and transition to a reduction stage.

Besides, it has been revealed that for prevention of transition to a reduction stage, small and medium enterprises should implement growth strategy that means introduction of the latest technologies. The technology is connected with new product development or services, which leads to emergence of project lifecycle, as it was revealed during the research. The last cycle, in case of its successful implementation, becomes the beginning of the new lifecycle of the whole enterprise.

It has been in turn revealed that for prevention of transition to a reduction stage, small and medium-sized enterprises have to employ the strategy of body height that is introduction of the latest technologies. The latter are bound to development of a new product or service, which causes as it was revealed during the research, the emergence of design life cycle. The last cycle, in case of its successful introduction, becomes the beginning of a new life cycle of the enterprise. In addition, it was defined that introduction of the project demands particular organizational construction at small and medium enterprises which corresponds to the 2 nd or 3rd stage of the life cycle.

However, the process of development of the project and creation of separate unit in organizational structure in the form of a project group needs further research within the project, namely: the analysis of costs on a new product or service, design risks and a zone of monitoring of participants of project group and, in the same manner, the management of the enterprise, etc. 


\section{REFERENCES}

1. Kolisnichenko, P.T. (2017). Situation and tendencies of development of small and medium business in Ukraine. Economy and society, 11. Retrieved from: http://economyandsociety.in.ua/journal-11/18-stati-11/1189-kolisnichenko-p-t [in Ukrainian].

2. Pavliuk, K. V. (2017). State support of development of small business in Ukraine and way of its perfecting. Proceedings of the Conference of doctoral candidates, young scientists and students Development of the European space by youth eyes: economic, social and legal aspects, Kharkiv (pp. 663 - 668). Kharkiv: FOP Panov AM. [in Ukrainian].

3. Svintsytska, O. M. (2017). Restructuring process as strategy of adaptation of the enterprises to changes of the external environment. Bulletin of the Zhytomyr state technological university. Series: Economic sciences, 3 (81), 89-92. Retrieved from: http://eztuir.ztu.edu.ua/123456789/7289 [in Ukrainian].

4. Gupta, R., \& Gupta, P. (2013). Individual dimensions of entrepreneurial orientation (EO) construct, resources and firm growth: evidence from Indian small \& medium enterprises (SME's)(summary). Frontiers of Entrepreneurship Research, 33(12), 5-12.

5. Lester, A. (2014). Project management, planning and control: managing engineering, construction and manufacturing projects to PMI, APM and BSI standards. Elsevier, (Six Edition).

6. Dziubina, A. V. (2012). Model operation of dynamics of life cycle of an innovative product. Efficient economy. (Vol. 9). Retrieved from: http://www.economy.nayka.com.ua/?op=1\&z=1414 [in Ukrainian].

7. Carvalho, K. L. D., Júnior, S., Freires, A., Frezatti, F., \& Costa, R. P. D. (2010). The contribution of organizational life cycle theories for management accounting research. RAM. Revista de Administração Mackenzie, 11(4), 98-130.

8. Santana, M., Valle, R., \& Galan, J. L. (2017). Turnaround strategies for companies in crisis: Watch out the causes of decline before firing people. BRQ Business Research Quarterly, 20(3), 206211.

9. Borysova, L. E. (2016) Formation of organizational structure of the telecommunication company on the process approach basis depending on a lifecycle stage. Prychornomorski ekonomichni studii, 9(1), 59-65 [in Ukrainian].

10. Borysova, L. E. (2017) The organizational component of development of the telecommunication enterprises at stages of life cycle. Phd thesis. Kyiv: SUT [in Ukrainian].

11. Kuznetsova, M. (Eds) (2016) The statistical publication: Activity of large, middle-size, small and micro-entrepreneurship entities. Kyiv: State Statistics Service of Ukraine. Retrieved from: www.ukrstat.gov.ua [in Ukrainian].

12. Reports on activity of Ministry of Economic Development and Trade of Ukraine 2017. (2017). Retrieved from: https://issuu.com/mineconomdev/docs/_3d7b2e9dcbae6c [in Ukrainian].

13. Presentation of full report "Annual score of business climate for 2016 - 2017" (2017) Retrieved from: https://www.slideshare.net/IER_Kyiv/2016-80646193 [in Ukrainian].

14. Quarter monitoring of obstacles in development of SME (2017) (7). Retrieved from: https://www.slideshare.net/IER_Kyiv/7-81515344 [in Ukrainian].

15. Official statistics of SME in Ukraine: analyze and proposal of the renewal. (2017). Retrieved from: https://www.slideshare.net/IER_Kyiv/ss-81431088.

16. Choi, G. E., Nordström, C., \& Llorach, C. (2012). The Organizational Life Cycle Stages and Effectiveness: A Study of Swedish Gazelle Companies. 


\section{ЛІТЕРАТУРА}

1. Колісніченко П.Т. Стан i тенденції розвитку малого та середнього підприємництва в Україні. Економіка та суспільство. 2017. № 11. URL: http://economyandsociety.in.ua/journal-11/18-stati-11/1189-kolisnichenko-p-t.

2. Павлюк К. В. Державна підтримка розвитку малого підприємництва в Україні та шляхи іiі вдосконалення. Розвиток європейського простору очима молоді: економічні, соціальні та правові аспекти: матеріали Всеукр. наук.-практ. конф. докторантів, молодих учених та студентів, 28 квіт. 2017 р. Харків: ФОП Панов А. М., 2017. С. 663 - 668.

3. Свінцицька О. М. Процес реструктуризації як стратегія адаптації підприємств до змін зовнішнього середовища. Вісник Житомирського державного технологічного університету. Сер. Економічні науки. 2017. № 3 (81). C. 89-92. URL: http://eztuir.ztu.edu.ua/123456789/7289.

4. Gupta R., Gupta P. Individual dimensions of entrepreneurial orientation (eo) construct, resources and firm growth: evidence from indian small \& medium enterprises (smes)(summary). Frontiers of Entrepreneurship Research. 2013. Vol. 33, № 12. P. 5.

5. Lester, A. (2014). Project management, planning and control: managing engineering, construction and manufacturing projects to PMI, APM and BSI standards. Elsevier, (Six Edition). 2014. P. 548.

6. Дзюбіна А. В. Моделювання динаміки життєвого циклу інноваційного продукту. Ефективна економіка. 2012. № 9. URL: http://www.economy.nayka.com.ua/?op=1\&z=1414 ) (дата звернення: 17.04.2018)

7. Carvalho K.L., Saraviva A.F., Costa Jr., R. P. The contribution of organizational life cycle theories for management accounting research. Rev. Adm. Mackenzie. 2010. № 4. Vol.11. P. 98-130.

8. Santana M., Valle R., Galan J. L. Turnaround strategies for companies in crisis: Watch out the causes of decline before firing people. BRQ Business Research Quarterly. 2017. URL: http://www.sciencedirect.com/science/article/pii/S2340943617300129.

9. Борисова Л. С. Процесний підхід до формування організаційної структури підприємства залежно від стадії життєвого циклу. Причорномор. екон. студії. 2016. Вип. 9(1). C. 59-65.

10. Борисова Л. Є. Організаційні складові розвитку телекомунікаційних підприємств на стадіях життєвого циклу: дис. ... канд. екон. наук: 08.00.04. / Державний ун-т телекомунікацій. Київ, 2017. 227 с.

11. Діяльність суб'єктів великого, середнього, малого та мікропідприємництва. Статистичний збірник, 2016. URL: www.ukrstat.gov.ua (дата звернення: 17.04.2018)
12. Звіт
Мінекономрозвитку
за
2017.
URL:

https://issuu.com/mineconomdev/docs/_3d7b2e9dcbae6c (дата звернення: 15.01.2018)

13. Презентація повного звіту «Щорічна оцінка ділового клімату 2016». URL: https://www.slideshare.net/IER_Kyiv/2016-80646193 (дата звернення: 17.04.2018)

14. Квартальний моніторинг перешкод у розвитку МСП. - 2017. -№7. URL: https://www.slideshare.net/IER_Kyiv/7-81515344 (дата звернення: 17.04.2018)

15. Офіційна статистика МСП в Україні: аналіз та пропозиції щодо вдосконалення. 2017. URL: https://www.slideshare.net/IER_Kyiv/ss-81431088.

16. Nordström C., Choi G. E., Llorach C. The Organizational Life Cycle Stages and Effectiveness: A Study of Swedish Gazelle Companies. Jönköping: JIBS. 2012. P. 53. 